\title{
Sindrom sagorijevanja i mentalno zdravlje kod medicinskog osoblja sa psihijatrijskog i nepsihijatrijskih odjela
}

1 Renata Sviben

2 Zrinka Pukljak Iričanin

3 Anita Lauri Korajlija

4 Ida Čular Reljanović

2 Katedra za zdravstvenu psihologiju, Zdravstveno veleučilište, Zagreb

3 Odsjek za psihologiju, Filozofski fakultet, Sveučilište u Zagrebu, Zagreb

4 Odjel psihijatrije, Opća bolnica Šibensko kninske županije, Šibenik

\section{Sažetak}

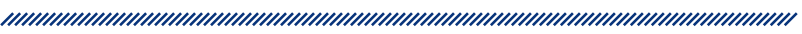

Cilj ovog istraživanja bio je ispitati sagorijevanje na poslu (definirano emocionalnom iscrpljenošću, depersonalizacijom i percepcijom smanjenoga osobnog postignuća) i mentalno zdravlje (definirano otpornošću na stres, subjektivnom procjenom zadovoljstva životom i izraženošću općih psihopatoloških smetnji) te usporediti stupnjeve sagorijevanja i mentalno zdravlje kod medicinskog osoblja s različitih odjela. Sudionici su bili 123 medicinske sestre / medicinska tehničara s nepsihijatrijskih i 51 sa psihijatrijskog odjela. Na cijelom uzorku rezultati ukazuju na visok stupanj emocionalne iscrpljenosti te umjerenu depersonalizaciju i osobno postignuće sudionika. Medicinske sestre / medicinski tehničari zadovoljni su životom, u prosjeku umjereno otporni na stres i nemaju izraženijih psihopatoloških odstupanja. Sudionici zaposleni na nepsihijatrijskim odjelima postižu visoke rezultate na skali emocionalne iscrpljenosti i umjerene rezultate na skali osobnog postignuća i depersonalizacije. Sudionici zaposleni na psihijatrijskom odjelu postižu umjerene rezultate na skali emocionalne iscrpljenosti, depersonalizacije i osobnog postignuća. Osoblje s nepsihijatrijskih odjela ima više osobno postignuće i višu razinu emocionalne iscrpljenosti od osoblja sa psihijatrijskog odjela.

Nisu utvrđene statistički značajne razlike u sagorijevanju i mentalnom zdravlju s obzirom na partnerski i roditeljski status osoblja na čitavom uzorku. Kod osoblja sa psihijatrijskog odjela dulji radni staž povezan je s višom razinom depersonalizacije i višom razinom općih psihopatoloških simptoma. S druge strane, kod nepsihijatrijskog osoblja dulji radni staž povezan je s višom razinom osobnog postignuća i višom otpornosti na stres. Rezultati pokazuju da između osoblja sa psihijatrijskog i nepsihijatrijskih odjela postoje određene razlike u dimenzijama sagorijevanja i njihovu odnosu s radnim stažem, što je važan nalaz u planiranju intervencija koje bi bile usmjerene na ublažavanje posljedica stresa na radnom mjestu.

Ključne riječi: sagorijevanje, otpornost na stres, zadovoljstvo životom, mentalno zdravlje

Datum primitka: 01.03.2017.

Datum prihvaćanja: 15.11.2017.

DOI: $10.24141 / 1 / 3 / 2 / 4$ 


\section{UVOD}

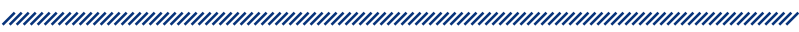

Istraživanja mentalnoga zdravlja kod zdravstvenih djelatnika važna su jer psihološke teškoće zdravstvenih djelatnika, osim što utječu na njihovo osobno i profesionalno funkcioniranje, mogu znatno utjecati i na kvalitetu skrbi o pacijentima.

Učestalost psiholoških problema kod zdravstvenih djelatnika veća je u odnosu na opću populaciju ${ }^{1}$. Istraživanja pokazuju da zdravstveni djelatnici u Americi imaju više stope samoubojstava i zlouporabe alkohola i droga, višu stopu hospitalizacija zbog psihičkih bolesti i višu stopu prijema u centre mentalnog zdravlja od opće populacije 2 . Francuski istraživači izvješćuju da $26 \%$ ženskog osoblja u bolnicama ima povećani rizik od oboljenja od psihičkih poremećaja. Štoviše, 32 \% sudionica izvještava o umoru, $31 \%$ o poremećajima spavanja, $28 \%$ o zlouporabi droge te $21 \%$ sudionica priznaje da ima psihijatrijsku dijagnozu, najčešće depresiju². Česte su i vrtoglavice, migrene, seksualne poteškoće, agresivnost i psihosomatski poremećaji ${ }^{3}$.

Osim toga, velik je problem među pomagačkim profesijama, pa tako i u sestrinstvu ${ }^{2,4,5,6}$, sindrom sagorijevanja na poslu (engl. burnout). Termin u stručnu literaturu 1974. godine uvodi američki psihoanalitičar Freudenberger i od tada se cijeli koncept intenzivno istražuje? Sagorijevanje nastaje u složenoj interakciji niza situacijskih (karakteristike i organizacija posla) i osobnih čimbenika (sociodemografske karakteristike, osobine ličnosti, stavovi prema poslu i sl. $)^{8}$, a uslijed duge izloženosti stresu na poslu. Javlja se kroz tri dimenzije: emocionalnu iscrpljenost, depersonalizaciju te doživljaj smanjenog osobnog postignuća ${ }^{8}$. Emocionalna iscrpljenost odnosi se na procjenu osobe da su njezine emocionalne snage osiromašene, što rezultira gubitkom energije i slabošću. To je ključna dimenzija sagorijevanja te kad opisujemo osobu u burnoutu najčešće opisujemo simptome emocionalne iscrpljenosti. No emocionalna iscrpljenost nije dovoljna za opis cijeloga ovog složenog fenomena ${ }^{8}$. Depersonalizacija se javlja kad osoba osjeti iscrpljenost te se počinje udaljavati od posla kako bi se uspješnije nosila s njegovim zahtjevima, postaje bešćutna i ima negativne ili pretjerano otuđene odgovore na druge ljude i aspekte posla. To ima negativne posljedice i na osobu i na druge ljude oko nje, a može dovesti do napuštanja posla i/ili rada kojim se zadovoljava nužni minimum, umjesto da se daje najbolje od sebe ${ }^{7,8}$. Na- posljetku, smanjeno osobno postignuće uključuje smanjenje osjećaja kompetencije i postignuća na poslu5. Ti se osjećaji javljaju kad se osoba duže vrijeme suočava s prevelikim zahtjevima, lošim međuljudskim odnosima, iscrpljenošću i cinizmom8.

U različitim istraživanjima sagorijevanja na poslu pronađena je povezanost između emocionalne iscrpljenosti i depersonalizacije, dok je veza između smanjenoga osobnog postignuća i drugih dviju dimenzija nešto složenija. Leiter ${ }^{9}$ predlaže da se emocionalna iscrpljenost javlja prva i vodi do razvoja depersonalizacije, dok se sniženo osobno postignuće razvija odvojeno. Čini se da taj paralelni razvoj odražava utjecaj različitih čimbenika u radnoj okolini ${ }^{10}$.

Kad je riječ o sagorijevanju u zdravstvu, dvije epidemiološke studije u Europi izvještavaju da sagorijevanje pogađa otprilike $25 \%$ zdravstvenog osoblja ${ }^{11}$. Tome pridonose brojne osobitosti rada zdravstvenih djelatnika - djelatnici često obavljaju poslove u uvjetima produljenog radnog vremena, smjenskog i noćnog rada, pri čemu imaju veliku odgovornost pri donošenju odluka. To može dovesti do pojave ozljeda i razvoja profesionalnih ili kroničnih bolesti, psihičkih smetnji i psihosomatskih bolesti ${ }^{12}$. Istraživanje stresa na poslu u zagrebačkim bolnicama pokazalo je da kao najstresnije aspekte posla zdravstveni djelatnici procjenjuju neadekvatna osobna primanja, neadekvatna materijalna sredstva za rad, nedostatan broj djelatnika, preopterećenost poslom i svakodnevne nepredvidive situacije ${ }^{13}$. Pri tome, kad se grupiraju brojni stresni podražaji, medicinske sestre najstresnijima procjenjuju različite aspekte organizacije posla i financijski aspekt te profesionalne zahtjeve koji se stavljaju pred njih ${ }^{13}$.

lako su zdravstveni djelatnici na psihijatrijskim odjelima izloženi sličnim stresnim podražajima na poslu kao i djelatnici na drugim odjelima, postoje i specifični stresni podražaji koji obilježavaju rad na psihijatrijskim odjelima ${ }^{4}$. Tako Happell i suradnici ${ }^{14}$ navode da čak do $70 \%$ osoblja zaposlenog na psihijatrijskim odjelima svake godine doživi neku vrstu nasilja na poslu. Ostali stresni podražaji odnose se na neadekvatnu pripremu osoblja, potencijalna samoubojstva pacijenata, ugrožavajuće i zahtjevne pacijente, verbalno zlostavljanje i nedostatak osoblja u potencijalno opasnim situacijama ${ }^{15}$. Posebno zahtjevnim radnim uvjetima izloženi su zdravstveni djelatnici zaposleni na forenzičkim psihijatrijskim odjelima. Smještaj pacijenata na te odjele često je posljedica teške psihičke bolesti zbog koje su pacijenti često agresivni, nepredvidivi i nasilni prema osoblju ${ }^{14,15}$. 
U skladu s time, različita dosadašnja istraživanja pokazuju da su medicinske sestre zaposlene na psihijatrijskim odjelima općenito u velikom riziku od sagorijevanja ${ }^{6,14,16,17,18,19,20,21}$ u usporedbi s medicinskim sestrama zaposlenima na drugim bolničkim odjelima te imaju više sagorijevanja na poslu ${ }^{11,22,23}$.

Osim rizičnih čimbenika za razvijanje sindroma sagorijevanja, treba spomenuti i zaštitne čimbenike - socijalna podrška iznimno je koristan mehanizam nošenja sa stresnim situacijama na poslu i umanjuje štetne posljedice stresa. Dvije su ključne vrste potpore. Emocionalna potpora odnosi se na informaciju dobivenu od onih koji nas poštuju i prihvaćaju, a instrumentalna potpora odnosi se na praktičnu pomoć drugih ljudi.

\section{Sociodemografske karakteristike i sagorijevanje}

Rezultati o povezanosti sociodemografskih karakteristika i sagorijevanja različiti su i još uvijek općenito neusuglašeni. Od svih ispitivanih sociodemografskih karakteristika dob je varijabla koja najčešće pokazuje povezanost sa sagorijevanjem, i to negativnu - mlađe sestre imaju više rezultate na pojedinim dimenzijama sagorijevanja $a^{4,8,11,18,24}$. No Ćurčić i Ćurčić25 nalaze da odnos između dobi i sagorijevanja, kao i radnog staža i sagorijevanja, nije linearan - sagorijevanje je najviše u dobnoj skupini između 31 i 50 godina, odnosno kod osoba koje imaju između 11 i 30 godina radnoga staža. Yousefy i Ghassemi ${ }^{15}$ dobivaju da povezanost dobi i radnoga staža sa sagorijevanjem ovisi o vrsti odjela. Osoblje zaposleno na psihijatriji uz višu dob, dulji radni staž i učestaliju frekvenciju poziva na dužnost ima i više rezultate na dimenzijama emocionalne iscrpljenosti i osobnog postignuća, dok je osoblje s nepsihijatrijskih odjela uz dulji radni staž manje emocionalno iscrpljeno ${ }^{15}$.

Što se tiče rodnih razlika, metaanaliza ${ }^{26}$ pokazuje da su žene u različitim zanimanjima češće emocionalno iscrpljene nego muškarci, dok je kod muškaraca viša depersonalizacija nego kod žena. $U$ istraživanjima na osoblju sa psihijatrijskih odjela Yousefy i Ghassemi ${ }^{15}$ dobivaju kod muškaraca više rezultate na emocionalnoj iscrpljenosti, a Kilfedder i suradnici ${ }^{18}$, Sahraian i suradnici ${ }^{27}$ te Cañadas-De la Fuente i suradnici ${ }^{28}$ više rezultate muškarca na depersonalizaciji.

lako Spooner-Lane ${ }^{11}$ navodi da većina studija ne pronalazi povezanost između sagorijevanja i bračnog statusa, Maslach ${ }^{8}$, Cañadas-De la Fuente i suradnici²8 i Lin ${ }^{29}$ izvještavaju o razlikama u dimenzijama sagorijevanja s obzirom na bračni status osoblja. Također, u istraživanju iranskih zdravstvenih djelatnika zaposlenih na odjelu za psihijatriju, internu medicinu, kirurgiju i odjelu za opekline izvještava se o razlikama u rezultatima na temelju bračnog statusa na dimenzijama sagorijevanja ${ }^{27}$. Na psihijatrijskim odjelima osoblje bez partnera bilo je emocionalno iscrpljenije i s manjim osobnim postignućem od osoblja u braku²7.

Iz svega navedenog jasno je da su zdravstveni djelatnici općenito izloženi brojnim stresnim podražajima na poslu. S obzirom na to da su istraživanja na ovu temu rijetka u Hrvatskoj, prvi je cilj ovog istraživanja bio utvrditi razinu sagorijevanja, otpornosti na stres, zadovoljstva životom i izraženost općih psihopatoloških smetnji kod medicinskih sestara/tehničara sa psihijatrijskih i nepsihijatrijskih odjela. Sljedeći je cilj bio te utvrditi eventualne razlike u sagorijevanju i mentalnom zdravlju između osoblja s različitih odjela. Konačno, željeli smo utvrditi razlike u navedenim varijablama s obzirom na sociodemografske varijable (partnerski i roditeljski status) i duljinu radnog staža. Očekivali smo da je osoblje sa psihijatrijskog odjela podložnije sindromu sagorijevanja, manje otporno na stres i zadovoljno životom te s više poteškoća i uznemirenije od osoblja zaposlenog na nepsihijatrijskim odjelima.

\section{METODA}

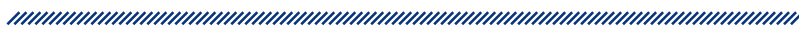

\subsection{Sudionici}

U istraživanju je sudjelovalo ukupno 174 sudionika podijeljenih u dvije skupine - osoblje zaposleno na psihijatrijskim odjelima i osoblje zaposleno na ostalim, nepsihijatrijskim odjelima.

Skupinu osoblja sa psihijatrijskog odjela činio je 51 sudionik zaposlen u jednoj psihijatrijskoj bolnici u Hrvatskoj. Skupinu osoblja s nepsihijatrijskih odjela činila su 123 izvanredna studenta preddiplomskog studija sestrinstva jednog veleučilišta u Hrvatskoj zaposlena na nepsihijatrijskim odjelima u bolnicama diljem Hrvatske.

Ukupno su istraživanjem obuhvaćene 134 medicinske sestre i 40 medicinskih tehničara. Deskriptivni podaci prikazani su u tablici 1. Prosječna je dob sudionika 35,66 (raspon od 23 do 62 godine), a prosječne godine radnog 


\begin{tabular}{l} 
Tablica 1. Spol, dob i godine radnog staža za osoblje sa psihijatrijskog ( $=51$ i nepsihijatrijskih \\
odjela ( $=123)$ \\
\hline \\
\hline
\end{tabular}

staža 15,65 (raspon od 2 do 42). U uzorku psihijatrijskog osoblja imamo podjednako sudionika oba spola (51 \% ženskog spola), dok je u uzorku nepsihijatrijskog osoblja znatno više žena $(87,8 \%)$. Većina je sudionika u braku $(68,4 \%)$ i ima jedno ili više djece (70,1\%).

\subsection{Instrumenti}

Osim upitnika kojim su prikupljeni podaci o dobi, spolu, studiju, godini studija, godinama radnog staža, specijalizaciji, bračnom statusu, broju djece i broju radnih sati tjedno, primijenjeni su i sljedeći mjerni instrumenti:

\subsubsection{Upitnik izgaranja na poslu Christine Maslach za stručnjake pomagačkih zanimanja (MBI-HSS Maslach Burnout Inventory - Human Services Survey)}

Maslach inventar sagorijevanja - uslužne djelatnosti, rad s ljudima sadrži 22 tvrdnje i služi za procjenu tri dimenzije sindroma sagorijevanja: emocionalna iscrpljenost (EI, devet čestica), depersonalizacija (DP, pet čestica) i osobno postignuće (OP, osam čestica). Sudionici procjenjuju tvrdnje na skali od sedam stupnjeva (od 0 - nikad do 6 - svaki dan).

Podljestvica emocionalne iscrpljenosti procjenjuje osjećaje emocionalne preopterećenosti $\mathrm{i}$ iscrpljenosti od posla (,Zbog posla se osjećam emocionalno iscrpljeno."). Rezultati se kreću u rasponu od 0 do 54. Rezultat od 0 do 16 bodova pokazatelj je niske, od 17 do 26 umjerene, a veći od 27 visoke emocionalne iscrpljenosti.

Podljestvica depersonalizacije procjenjuje stupanj u kojem osoba iskazuje neosjetljivost ili dehumanizirani stav prema klijentima (pacijentima) kojima pruža usluge (,Zapravo me nije briga što se događa s nekim mojim pacijentima."). Rezultati se kreću u rasponu od 0 do 30. Rezultat od 0 do 6 pokazatelj je niske, od 7 do 12 umjerene, a veći od 13 visoke depersonalizacije.
Podljestvica osobnog postignuća mjeri osjećaj kompetencije i uspjeha koje osoba ima na svojem poslu (,Vrlo sam efikasna u rješavanju problema svojih pacijenata.”). Rezultati se kreću u rasponu od 0 do 48. Rezultat viši od 39 pokazatelj je visokog, od 32 do 38 umjerenog, a manji od 31 niskog osobnog postignuća.

Autori ne preporučuju iskazivanje jedinstvenog ukupnog rezultata, već se iskazuju rezultati svake dimenzije posebno (10). Što je rezultat na podljestvici emocionalnog iscrpljenja i depersonalizacije viši, veći je i stupanj sagorijevanja. Rezultat na ljestvici osobnog postignuća i stupanj sagorijevanja povezani su u suprotnom smjeru - viši rezultat na osobnom postignuću pokazatelj je nižeg sagorijevanja.

Značajne simptome profesionalnog sagorijevanja ima svaka osoba s visokim rezultatima na ljestvici emocionalne iscrpljenosti i depersonalizacije te niskim rezultatom na ljestvici percepcije osobnog postignuća.

$\mathrm{U}$ ovom je istraživanju Cronbachov $\alpha$-koeficijent pouzdanosti za sve tri dimenzije zadovoljavajući: za podljestvicu emocionalne iscrpljenosti $\alpha=0,91$, za depersonalizaciju $\alpha=0,77$ te za osobno postignuće $\alpha=0,76$.

\subsubsection{Upitnik otpornosti na stres (Karazman i Mustajbegović, 2003) (30 $^{30}$}

Upitnik otpornosti na stres sadrži 20 tvrdnji. Sudionici na skali od 0 do 10 procjenjuju koliko se tvrdnja (npr. „Imam dobru ljubavnu vezu i sretan sam sa svojim partnerom.") odnosi na njih (0 - uopće se ne odnosi na mene, 10 - u potpunosti se odnosi na mene). Zbroj rezultata svih tvrdnji označava intenzitet otpornosti na stres, pri čemu viši rezultati upućuju na veću otpornost. Mogući je raspon rezultata od 0 do 200 . Upitnik je već do sada upotrijebljen $u$ istraživanjima profesionalnog stresa na različitim uzorcima ${ }^{31,32,33}$. U istraživanju je Cronbachov $\alpha$-koeficijent zadovoljavajući i iznosi $\alpha=0,79$. 


\subsubsection{Upitnik za ispitivanje općih psihopa- toloških teškoća CORE-OM (Clinical Outcomes in Routine Evaluation - Outcome Measure) ${ }^{34}$}

Instrument je osmišljen kao panteorijska i pandijagnostička mjera opće psihičke uznemirenosti koja se upotrebljava na svim razinama psihološke skrbi, od trijaže do praćenja psihoterapijskih učinaka ${ }^{34}$. Sastoji se od 34 čestice. Zadatak je sudionika procijeniti koliko se često osjećao na opisani način tijekom protekla dva tjedna (0 - nikada, 1 - vrlo rijetko, 2 - ponekad, 3 - često, 4 - gotovo uvijek). Čestice se odnose na četiri dimenzije. Prva je subjektivna dobrobit i obuhvaća četiri čestice (npr. „Bila sam optimistična u vezi sa svojom budućnošću."). Druga je dimenzija problemi/simptomi i obuhvaća 12 čestica (npr. „Uznemiravale su me neželjene misli i osjećaji.”). Treća je svakodnevno funkcioniranje i obuhvaća 12 čestica (npr. „Mogla sam se nositi s poteškoćama.”). Četvrta je dimenzija rizik i obuhvaća šest čestica (npr. „Razmišljala sam kako bi bilo bolje da me nema.").

Ukupni rezultat predstavlja zbroj svih čestica i kreće se od 0 do 136. Može se izračunati i ukupni prosječni rezultat, i to tako da se ukupni rezultat podijeli sa 34 . Što je ukupni rezultat viši, osoba ima više problema i uznemirenija je ${ }^{34}$. $U$ ovom je istraživanju Cronbachov $\alpha$-koeficijent vrlo visok i iznosi $\alpha=0,95$.

Od sudionika se tražilo i da na jednoj čestici procjene koliko su sveukupno zadovoljni svojim životom. Subjektivnu procjenu zadovoljstva životom iskazivali su na skali od 10 stupnjeva ( 1 - potpuno nezadovoljan, 5 - ni nezadovoljan ni zadovoljan, 10 - potpuno zadovoljan).

\subsection{Postupak}

Svi sudionici su upoznati s ciljem istraživanja te im je objašnjeno da je njihovo sudjelovanje $u$ istraživanju dragovoljno i anonimno. Na veleučilištu su sudionici ispunjavali upitnike na početku predavanja, te je ispunjavanje trajalo oko 20 minuta. Ispunjeno je i vraćeno $100 \%$ upitnika. U bolnici je glavna sestra bolnice isporučila upitnike na odjele te ih je, u zatvorenim omotnicama, prikupila nakon deset dana. Ispunjeno je i vraćeno $51 \%$ upitnika. Istraživanje su odobrila etička povjerenstva veleučilišta i psihijatrijske bolnice u kojima je provođeno.

\section{REZULTATI}

Statistička obrada prikupljenih podataka provedena je s pomoću statističkog programa SPSS 17.0 for Windows.

U tablici 2 prikazani su postoci sudionika koji imaju visok, umjeren i nizak rezultat na pojedinim dimenzijama sagorijevanja. Na dimenziji emocionalne iscrpljenosti najviše medicinskih sestara/tehničara pokazuje visoko sagorijevanje (46\%), na dimenziji depersonalizacije najviše $(42,5 \%)$ medicinskih sestara/tehničara nalazi se u kategoriji niske, a na dimenziji osobnog postignuća najviše je medicinskih sestara/tehničara $(33,3 \%)$ u kategoriji umjerenog postignuća. Gotovo polovica psihijatrijskog osoblja u kategoriji je visokoga osobnog postignuća (49\%).

Znatne simptome profesionalnog sagorijevanja ima svaka osoba s visokim rezultatima na ljestvici emocionalne iscrpljenosti i depersonalizacije te niskim rezultatom na ljestvici percepcije osobnog postignuća (5). U ovom istraživanju takve rezultate postiglo je 15 medicinskih sestara/tehničara, šest sa psihijatrijskog i devet s nepsihijatrijskih odjela, odnosno 8,6 \% cijelog uzorka.

\begin{tabular}{l}
\multicolumn{8}{|c|}{ Tablica 2. Postotak sudionika koji na pojedinim dimenzijama upitnika MBI imaju visok, } \\
umjeren ili nizak rezultat \\
\hline Rezultat
\end{tabular}


Razlika u učestalosti visokog stupnja sagorijevanja između psihijatrijskih i nepsihijatrijskih odjela nije statistički značajna $\left(\chi^{2}=1,61, d f=1\right)$.

Usporedba pojedinih dimenzija sagorijevanja pokazala je postojanje određenih razlika između osoblja sa psihijatrijskih i nepsihijatrijskih odjela (tablica 3).

$\mathrm{Na}$ dimenziji emocionalne iscrpljenosti prosječni rezultat cijelog uzorka $(M=26,67 ; S D=12,05)$, prema Maslach i suradnicima ${ }^{10}$, u kategoriji je visoke emocionalne iscrpljenosti. Medicinske sestre / medicinski tehničari s nepsihijatrijskih odjela imaju visok rezultat, a medicinske sestre / medicinski tehničari sa psihijatrijskog odjela rezultat koji odgovara umjerenoj emocionalnoj iscrpljenosti. Ta je razlika statistički značajna $(t=-2,69$; $p<0,05)$.

Na dimenziji depersonalizacije ukupni prosječni rezultat $(M=8,17 ; S D=6,16)$ i rezultati obje grupe vrlo su slični i statistički se značajno ne razlikuju $(t=0,15 ; p>0,01)$. Medicinske sestre / medicinski tehničari sa psihija- trijskih i nepsihijatrijskih odjela nalaze se u kategoriji umjerene depersonalizacije.

Na dimenziji osobnog postignuća rezultat ukupnog uzorka $(M=34,16$; $S D=7,01)$ u kategoriji je umjerenoga osobnog postignuća. lako se obje grupe pojedinačno također nalaze u kategoriji umjerenoga osobnog postignuća, razlika je između osoblja sa psihijatrijskih i nepsihijatrijskih odjela. Medicinske sestre / medicinski tehničari sa psihijatrijskog odjela imaju niži rezultat na osobnom postignuću, što znači više sagorijevanje.

Dakle, osoblje s nepsihijatrijskih odjela statistički je značajno više emocionalno iscrpljeno, ali imaju i višu percepciju osobnog postignuća u odnosu na one sa psihijatrijskog odjela (tablica 3).

Subjektivna procjena zadovoljstva životom na ukupnom uzorku ukazuje da su zdravstveni djelatnici zadovoljni svojim životom te da nema razlika među medicinskim osobljem sa psihijatrijskih i nepsihijatrijskih odjela $(t=0,81 ; p>0,05)$. Rezultat na ukupnom uzorku

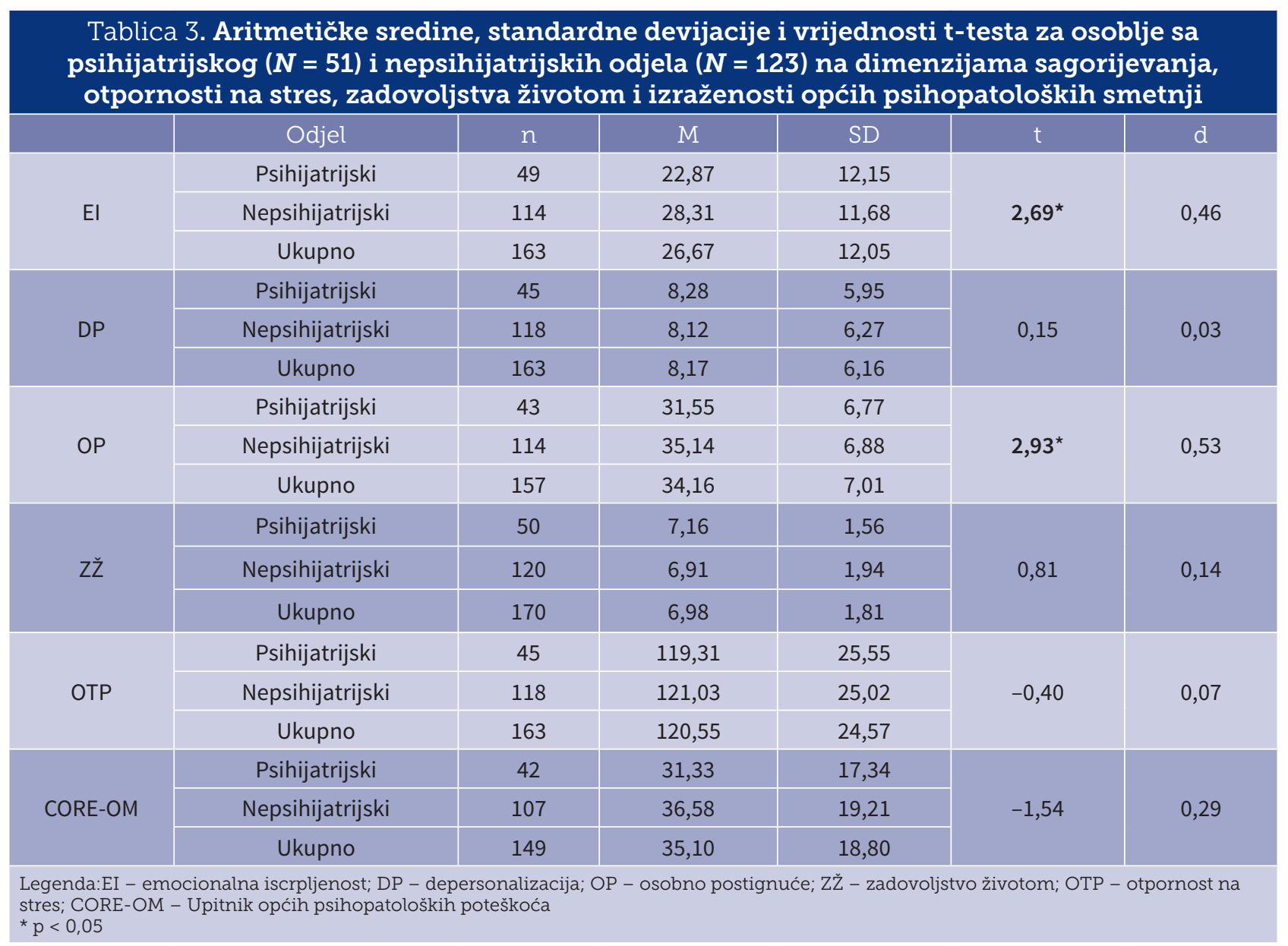


za otpornost na stres ukazuje da su zdravstveni djelatnici umjereno otporni na stres te ponovno nisu utvrđene razlike među grupama ( $\mathrm{t}=-0,40 ; p>0,05)$. Prosječni rezultat izraženosti općih psihopatoloških smetnji ukazuje na to da osoblje i na psihijatrijskim i nepsihijatrijskim odjelima izvještava o malo problema i niskoj razini uznemirenosti koja je ispod graničnog rezultata ${ }^{35}$ $(p>0,5)$.

Ispitane su i razlike u varijablama sagorijevanja, zadovoljstva životom, otpornosti na stres i stupnju psihopatoloških smetnji s obzirom na neke sociodemografske karakteristike sudionika. Nisu nađene razlike u pokaza- teljima sagorijevanja i mentalnog zdravlja ni s obzirom na partnerski ni s obzirom na roditeljski status (tablica 4).

$S$ obzirom na to da je dob vrlo visoko korelirala s duljinom radnog staža $(r=0,96, p<0,01)$, prikazani su samo rezultati za duljinu radnog staža. $U$ našem istraživanju duljina radnog staža na cijelom uzorku nije povezana s dimenzijama sagorijevanja, otpornosti na stres, zadovoljstvom životom i izraženosti općih psihopatoloških smetnji (tablica 5). No utvrđeni su zanimljivi različiti obrasci u povezanostima među tim varijablama unutar uzoraka. Kod osoblja sa psihijatrijskog odjela dulji radni staž povezan je s višom depersonalizacijom $(r=0,34$,

\begin{tabular}{|c|c|c|c|c|c|c|c|c|c|c|}
\hline & Partner & $\mathrm{N}$ & M & $\mathrm{SD}$ & $\begin{array}{c}\mathrm{t} \\
\text { (d) }\end{array}$ & Djeca & $\mathrm{N}$ & M & SD & $\begin{array}{c}\mathrm{t} \\
\text { (d) }\end{array}$ \\
\hline \multirow{2}{*}{$E$} & DA & 121 & 27,33 & 12,29 & \multirow{2}{*}{$\begin{array}{c}1,22 \\
(0,23)\end{array}$} & DA & 113 & 26,71 & 11,65 & \multirow{2}{*}{$\begin{array}{c}0,07 \\
(0,01)\end{array}$} \\
\hline & NE & 40 & 24,67 & 10,84 & & $N E$ & 50 & 26,58 & 13,01 & \\
\hline \multirow{2}{*}{ DP } & DA & 120 & 8,54 & 6,44 & \multirow{2}{*}{$\begin{array}{c}1,21 \\
(0,23)\end{array}$} & DA & 112 & 7,89 & 5,97 & \multirow{2}{*}{$\begin{array}{c}-0,86 \\
(0,14)\end{array}$} \\
\hline & NE & 40 & 7,19 & 5,26 & & NE & 50 & 8,78 & 6,58 & \\
\hline \multirow{2}{*}{$\mathrm{OP}$} & DA & 117 & 34,01 & 6,82 & \multirow{2}{*}{$\begin{array}{l}-1,13 \\
(0,21)\end{array}$} & DA & 107 & 34,32 & 7,22 & \multirow{2}{*}{$\begin{array}{c}0,04 \\
(0,07)\end{array}$} \\
\hline & NE & 38 & 35,44 & 6,83 & & NE & 50 & 33,82 & 6,61 & \\
\hline \multirow{2}{*}{ Zž } & DA & 127 & 7,13 & 1,86 & \multirow{2}{*}{$\begin{array}{c}1,57 \\
(0,29)\end{array}$} & DA & 119 & 7,11 & 1,83 & \multirow{2}{*}{$\begin{array}{c}1,38 \\
(0,23)\end{array}$} \\
\hline & NE & 41 & 6,61 & 1,73 & & NE & 51 & 6,69 & 1,84 & \\
\hline \multirow{2}{*}{ OTP } & DA & 121 & 121,71 & 24,92 & \multirow{2}{*}{$\begin{array}{c}0,58 \\
(0,11)\end{array}$} & DA & 113 & 121,74 & 24,73 & \multirow{2}{*}{$\begin{array}{c}0,93 \\
(0,16)\end{array}$} \\
\hline & $\mathrm{NE}$ & 40 & 119,17 & 21,81 & & NE & 50 & 117,88 & 24,21 & \\
\hline \multirow{2}{*}{ CORE-OM } & DA & 110 & 35,01 & 19,21 & \multirow{2}{*}{$\begin{array}{c}0,32 \\
(0,06)\end{array}$} & DA & 105 & 35,23 & 18,94 & \multirow{2}{*}{$\begin{array}{c}0,13 \\
(0,02)\end{array}$} \\
\hline & NE & 37 & 33,94 & 17,47 & & NE & 44 & 34,79 & 18,65 & \\
\hline
\end{tabular}

Legenda: EI - emocionalna iscrpljenost; DP - depersonalizacija; OP - osobno postignuće; ZŽ - zadovoljstvo životom; OTP - otpornost na stres; CORE-OM - Upitnik općih psihopatoloških poteškoća

Tablica 5. Pearsonovi koeficijenti korelacije dimenzija sagorijevanja, otpornosti na stres, zadovoljstva životom, izraženosti općih psihopatoloških smetnji s duljinom radnog staža

\begin{tabular}{|c|c|c|c|}
\hline & & \multicolumn{2}{|c|}{ Duljina radnog staža } \\
\hline & Obje skupine & Osoblje sa psihijatrijskog odjela & $\begin{array}{c}\text { Osoblje s } \\
\text { nepsihijatrijskih odjela }\end{array}$ \\
\hline Emocionalna iscrpljenost & 0,06 & 0,18 & 0,08 \\
\hline Depersonalizacija & 0,01 & $0,34^{*}$ & $-0,21$ \\
\hline Osobno postignuće & 0,12 & $-0,03$ & $0,30^{\star \star}$ \\
\hline Zadovoljstvo životom & $-0,09$ & $-0,28$ & $-0,02$ \\
\hline Otpornost na stres & 0,05 & $-0,16$ & $0,19^{\star *}$ \\
\hline CORE-OM & 0,12 & $0,42^{\star \star}$ & 0,02 \\
\hline
\end{tabular}

Legenda: CORE-OM - Upitnik općih psihopatoloških poteškoća ${ }^{\star} \mathrm{p}<0,05 ;{ }^{* *} \mathrm{p}<0,01$ 
$p<0,05)$ te brojem poteškoća i osjećajem uznemirenosti $(r=0,42, p<0,01)$. Kod osoblja s nepsihijatrijskih odjela dulji radni staž povezan je s višim osjećajem osobnog postignuća $(r=0,30, p<0,01)$ i višom otpornošću na stres $(r=0,19, p<0,01)$.

Budući da rezultati nekih dosadašnjih istraživanja pokazuju da odnos duljine radnog staža i dimenzija sagorijevanja nije linearan ${ }^{25}$, varijablu duljina radnog staža podijelili smo na tri kategorije: kratki radni staž (do devet godina), srednji radni staž (10 do 20 godina) i dugi radni staž (više od 21 godine). Proveli smo jednostavnu analizu varijance kako bismo ispitali postoje li razlike na dimenzijama sagorijevanja, otpornosti na stres i izraženosti općih psihopatoloških smetnji s obzirom na te kategorije. Rezultati prikazani u tablici 6 pokazuju da je razlika među sudionicima različite duljine radnog staža dosegnula statističku značajnost na dimenziji emocionalne iscrpljenosti $(F=3,08 ; d f=2 / 159 ; p<0,05)$. Post hoc testiranjem Tukeyjevim HSD testom pokazalo se da je razlika značajna između grupe s kratkim i one sa srednjim radnim stažem, pri čemu oni s kratkim stažem imaju višu razinu emocionalne iscrpljenosti od onih sa srednjim radnim stažem.

\section{DISKUSIJA}

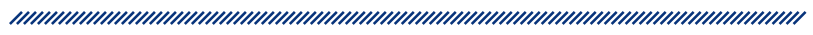

Brojna istraživanja na zdravstvenim djelatnicima utvrdila su povezanost određenih bolesti sa stresom na radu, poput povećanog rizika za pojavu koronarne bolesti i psihičkih poremećaja. Zdravstvena struka s obzirom na odgovornost prema ljudskom životu i zdravlju, ali i izloženost specifičnim stresnim podražajima poput kemijskih, bioloških i fizikalnih štetnosti te smjenskom radu jedna je od najosjetljivijih struka gdje djelatnici mogu završiti svoj radni vijek s brojnim posljedicama ${ }^{36}$. Istraživanja pokazuju da sagorijevanje pogađa otprilike $25 \%$ zdravstvenog osoblja $^{11}$, a $26 \%$ osoblja sa psihijatrijskih odjela ${ }^{26}$.

Stoga je cilj našeg istraživanja bio ispitati sagorijevanje na poslu (definirano emocionalnom iscrpljenošću, depersonalizacijom i percepcijom smanjenoga osobnog postignuća) i mentalno zdravlje (definirano otpornošću na stres, subjektivnom procjenom zadovoljstva životom i izraženošću općih psihopatoloških smetnji) kod medicinskih sestara/tehničara sa psihijatrijskih i nepsihijatrijskih odjela.

\begin{tabular}{|c|c|c|c|c|c|}
\hline & Trajanje staža & $\mathrm{N}$ & $\bar{M}$ & $\overline{S D}$ & $\bar{F}$ \\
\hline \multirow{3}{*}{ Emocionalna iscrpljenost } & do 9 god. & 37 & 23,10 & 12,83 & \multirow{3}{*}{$3,08^{*}$} \\
\hline & 10 do 20 god. & 90 & 28,68 & 11,41 & \\
\hline & više od 21 god. & 35 & 25,71 & 11,97 & \\
\hline \multirow{3}{*}{ Depersonalizacija } & do 9 god. & 39 & 7,89 & 5,76 & \multirow{3}{*}{0,10} \\
\hline & 10 do 20 god. & 89 & 8,40 & 6,47 & \\
\hline & više od 21 god. & 34 & 8,08 & 5,88 & \\
\hline \multirow{3}{*}{ Osobno postignuće } & do 9 god. & 40 & 33,37 & 6,85 & \multirow{3}{*}{1,32} \\
\hline & 10 do 20 god. & 83 & 33,84 & 7,41 & \\
\hline & više od 21 god. & 33 & 35,87 & 6,17 & \\
\hline \multirow{3}{*}{ Otpornost na stres } & do 9 god. & 40 & 122,35 & 23,60 & \multirow{3}{*}{0,18} \\
\hline & 10 do 20 god. & 86 & 119,51 & 24,84 & \\
\hline & više od 21 god. & 36 & 120,75 & 25,76 & \\
\hline \multirow{3}{*}{ Zadovoljstvo životom } & do 9 god. & 35 & 7,32 & 5,84 & \multirow{3}{*}{1,74} \\
\hline & 10 do 20 god. & 93 & 6,88 & 5,46 & \\
\hline & više od 21 god. & 40 & 6,79 & 6,36 & \\
\hline \multirow{3}{*}{ CORE-OM } & do 9 god. & 36 & 32,77 & 19,59 & \multirow{3}{*}{0,47} \\
\hline & 10 do 20 god. & 79 & 35,32 & 18,69 & \\
\hline & više od 21 god. & 33 & 37,15 & 19,59 & \\
\hline
\end{tabular}

Legenda: CORE-OM - Upitnik općih psihopatoloških poteškoća ${ }^{*} \mathrm{p}<0,05$ 
Rezultati pokazuju da se $46 \%$ osoblja nalazi u kategoriji visoke emocionalne iscrpljenosti, $23 \%$ osoblja ima visoku depersonalizaciju, a nisko osobno postignuće ima $24,7 \%$ osoblja. Dakle, gotovo polovina sudionika osjeća se iscrpljeno i preopterećeno poslom, gotovo in se četvrtina odnosi prema pacijentima kao da su anonimni objekti, distancirani su od posla i cinični te se osjećaju neuspješno.

Oko 8,6 \% ukupnog uzorka ima simptome visokoga profesionalnog sagorijevanja, što je niže od većine podatka koji se spominju u literaturi',11,26, iako postoje i istraživanja u kojima je dobivena manja proporcija medicinskih sestara s visokim sagorijevanjem ${ }^{18}$. Pri usporedbi sestara/tehničara sa psihijatrijskih i nepsihijatrijskih odjela nije nađena statistički značajna razlika u učestalosti visokoga profesionalnog sagorijevanja, iako su neka prethodna istraživanja pokazivala taj trend $d^{11,22,23}$.

Rezultati pokazuju da su razlike između osoblja sa psihijatrijskog i osoblja s nepsihijatrijskih odjela statistički značajne na dimenzijama emocionalne iscrpljenosti i osobnog postignuća. Osoblje zaposleno na nepsihijatrijskim odjelima doživljava višu razinu emocionalne iscrpljenosti i više osobno postignuće od psihijatrijskog osoblja. lako dobivene razlike mogu biti posljedica razlika u odjelima na kojima osoblje radi, treba napomenuti da su sudionici s nepsihijatrijskih odjela ujedno i izvanredni studenti te je moguće da je i činjenica da se trenutačno školuju utjecala na rezultate. $U$ istraživanju sagorijevanja osoblja zaposlenog na psihijatrijskim odjelima koje su proveli Ogresta i suradnici ${ }^{6}$ dobivene su umjerena emocionalna iscrpljenost i depersonalizacija te visoko osobno postignuće. Hudek-Knežević i suradnici $u$ istraživanju na medicinskim sestrama dobivaju visoku razinu emocionalne iscrpljenosti, nisku depersonalizaciju i visoko osobno postignuće ${ }^{37}$.

U istraživanju psihijatrijskih medicinskih sestra u Južnoj Africi dobivene su visoke razine sagorijevanja na sve tri dimenzije ${ }^{19}$, dok je istraživanje psihijatrijskog osoblja u Jordanu pokazalo visoku razinu emocionalne iscrpljenosti te umjerene razine depersonalizacije i osobnog postignuća ${ }^{17}$. U Americi, Škotskoj i Australiji osoblje pokazuje umjerenu emocionalnu iscrpljenost i nisku depersonalizaciju, ali postoje razlike na dimenziji osobnog postignuća - u Americi je visoko, u Škotskoj umjereno, a u Australiji nisko ${ }^{14,18,38}$. Osoblje s nepsihijatrijskih odjela također je imalo više rezultate na gotovo svim ispitivanim varijablama osim depersonalizacije, međutim te razlike nisu dosegnule razinu značajnosti. Istraživanje u Poljskoj ${ }^{39}$ također je utvrdilo razlike između osoblja zaposlenog na psihijatrijskim i nepsihijatrijskim odjelima. U navedenom istraživanju umjerene i visoke razine emocionalne iscrpljenosti imalo je $71 \%$ sudionika, depersonalizacije 39,8 \% sudionika, a osobnog postignuća $77 \%$ sudionika ${ }^{39}$. Rezultati našeg istraživanja slični su opisanima, s razlikom da više osoblja ima višu depersonalizaciju, ali zato manje osoblja ima umjereno ili više osobno postignuće.

Djeca i obitelj predstavljaju financijsku i emocionalnu odgovornost. Ako osoblje radi u smjenama, izazovi organizacije i usklađivanja obiteljskog i profesionalnog života mogu predstavljati dodatne stresne podražaje, uz one koji već postoje na radnom mjestu ${ }^{20}$. Nedostatna podrška ukućana može dovesti do smanjene otpornosti na stres, niže procjene zadovoljstva životom i poteškoća u psihičkom funkcioniranju. S druge strane, moguće je i da partneri budu izvor socijalne podrške te da, zajedno s djecom, pridonose zadovoljstvu životom. Dobiveni rezultati ne ukazuju na razlike među osobljem s obzirom na partnerski i roditeljski status na dimenzijama sagorijevanja, otpornosti na stres, procjeni zadovoljstva životom i izraženosti općih psihopatoloških smetnji. Rezultati istraživanja Kararića i suradnika ${ }^{36}$ na studentima sestrinstva, koje obuhvaća sestre s različitih odjela koje su već zaposlene, također ne ukazuje na razlike u zadovoljstvu životom s obzirom na bračni status. Ove rezultate možemo promatrati u kontekstu istraživanja socijalne podrške kod zdravstvenih djelatnika koja pokazuju da je u sprječavanju sagorijevanja zdravstvenih djelatnika učinkovitija potpora kolega i supervizora koji su upoznati sa specifičnostima posla od potpore dobivene od partnera, obitelji i prijatelja ${ }^{11}$.

Što se tiče sociodemografskih karakteristika i sagorijevanja, dosadašnja istraživanja pokazuju da dob negativno korelira sa sagorijevanjem ${ }^{4,8,11,18,24}$. Mlađe sestre izvještavaju o višoj emocionalnoj iscrpljenosti i depersonalizaciji te nižem postignuću, za razliku od starijih sestara kojima iskustvo, znanje i način nošenja sa stresom pomažu da ne sagore na poslu. No često odnos dobi i radnog staža nije linearan s dimenzija sagorijevanja ${ }^{25}$.

Nadalje, neka su istraživanja već pokazala da se odnos dobi i staža s dimenzijama sagorijevanja razlikuje na psihijatrijskim i nepsihijatrijskim odjelima ${ }^{15}$. Stoga smo ispitali razlike u povezanosti dobi i godina radnog staža s dimenzijama sagorijevanja, otpornosti na stres, zadovoljstva životom i izraženosti općih psihopatoloških smetnji na različitim odjelima. Rezultati pokazuju da na cijelom uzorku nema znatne povezanosti između dobi i godina radnog staža s dimenzijama sagorijevanja, otpornosti na stres, zadovoljstva životom i izraženosti općih psihopatoloških smetnji na cijelom uzorku. No 
provjera povezanosti duljine staža s mjerenim varijablama unutar psihijatrijskog i nepsihijatrijskog uzorka pokazala je znatne razlike. Kod psihijatrijskih medicinskih sestara dulji radni staž povezan je s višom depersonalizacijom te brojem problema i smetnji, dok je kod nepsihijatrijskih sestara dulji radni staž povezan s višim osjećajem osobnog postignuća i otpornosti na stres. Ovakvi nalazi ukazuju da povećanje duljine rada na psihijatrijskim odjelima kod medicinskih sestara dovodi do pojave teškoća u funkcioniranju, dok porast radnog iskustva na sestre na nepsihijatrijskim odjelima djeluje pozitivno. Možemo pretpostaviti da su jedan od izvora navedenih razlika specifičnosti rada sa psihijatrijskim pacijentima. Pri tome valja naglasiti da u ovom istraživanju medicinske sestre sa psihijatrijskih odjela imaju više godina radnog staža od nepsihijatrijskog osoblja pa spomenute rezultate treba uzeti s rezervom, a spomenuti trend dodatno istražiti.

U skladu s prethodnim istraživanjima osoblja na psihijatrijskim klinikama ${ }^{25}$, duljinu radnog staža podijelili smo u tri kategorije: malo staža (do devet godina), srednje staža (10 do 20 godina) i mnogo staža (više od 21 godine). Pokazalo se da osoblje najvišu razinu emocionalne iscrpljenosti doživljava između 10 i 20 godina radnog staža, $\mathrm{tj}$. između tridesete i četrdesete godine života, kao i u spomenutom istraživanju ${ }^{25}$. Razlike među grupama različite duljine staža na ostalim dimenzijama nisu se pokazale statistički značajnima.

Sociodemografske varijable nisu se pokazale značajnima u objašnjenju fenomena sagorijevanja na poslu, a one koje se tiču duljine radnog staža donekle jesu, čime se potvrđuje da je riječ o psihičkim smetnjama koje su povezane s čimbenicima povezanima s poslom, a ne stresu općenito. Nalazi u ovom istraživanju upućuju na važnu ulogu karakteristika posla u psihološkom funkcioniranju zdravstvenih djelatnika, pri čemu je utjecaj obiteljskih čimbenika slabije izražen. Za sigurnije zaključke bilo bi potrebno primijeniti preciznije metodološke i statističke postupke.

\subsection{Metodološki nedostaci i smjernice za buduća istraživanja}

Provedeno istraživanje ima određena metodološka ograničenja koja su mogla utjecati na dobivene rezultate. Potrebno ih je spomenuti kako bi se poboljšala buduća istraživanja na istu temu.

Broj sudionika u ovom istraživanju nije reprezentativan za cijelu populaciju medicinskog osoblja u Hrvatskoj. Uzorak čine samo 174 medicinske sestre / medicinska tehničara, a uzorak osoblja sa psihijatrijskog odjela dvostruko je manji. $U$ daljnjim istraživanjima trebalo bi povećati broj sudionika za pojedine odjele, ali i provjeriti postoje li razlike između odjela (ne samo psihijatrijskih i nepsihijatrijskih). Što se tiče osoblja sa psihijatrijskog odjela, svi dolaze iz iste ustanove iz jednog grada, što dovodi u pitanje mogućnost generalizacije rezultata. Također, statističke su analize koje se mogu provoditi na ovolikom uzorku ograničene, a dobiveni rezultati moraju se uzeti s oprezom.

Istraživači očekuju da će sudionici biti iskreni prilikom odgovaranja na postavljena pitanja. Međutim, ponekad sudionici ne odgovaraju iskreno, već odgovaraju na socijalno poželjan način. U ovakvoj vrsti istraživanja, gdje su primijenjene mjere samoprocjene, može se pretpostaviti da su neki odgovarali na socijalno poželjan način i tako iskrivljavali svoje odgovore u smjeru umanjivanja smetnji.

Uz navedene smjernice, daljnja bi istraživanja trebala provjeriti što osoblje smatra stresnim u svojem poslu, zatim količinu izbivanja s posla (bolovanja) koje je povezano sa zdravljem, povezanost noćnih smjena i navedenih varijabli, je li motiviranost osoblja čimbenik u borbi protiv sagorijevanja te koliko osoblje osjeća potrebu za supervizijom, koja se u nekim slučajevima pokazala korisnom u smanjivanju stresa na poslu. Također, trebalo bi provjeriti postoje li rodne razlike u sagorijevanju i mentalnom zdravlju osoblja zaposlenog na psihijatrijskim i nepsihijatrijskim odjelima te odnose između ispitivanih varijabli provjeriti u longitudinalnim istraživanjima.

lako postoje nedostaci u ovom istraživanju, ono je svejedno prvo istraživanje u Hrvatskoj koje je provjeravalo razliku u sagorijevanju i mentalnom zdravlju između medicinskih sestara/tehničara sa psihijatrijskih i nepsihijatrijskih odjela i time dalo svoj doprinos razumijevanju sindroma sagorijevanja.

\section{ZAKLJUČAK}

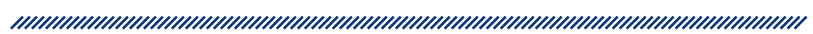

Rezultati pokazuju da se kod ispitanog osoblja uočavaju znakovi početnog sagorijevanja te da 8,6 \% ukupnog uzorka ispunjava kriterije za sagorijevanje na poslu.

Sudionici zaposleni na nepsihijatrijskim odjelima postižu visoke rezultate na skali emocionalne iscrpljenosti i 
umjerene rezultate na skali osobnog postignuća i depersonalizacije. Sudionici zaposleni na psihijatrijskom odjelu postižu umjerene rezultate na skali emocionalne iscrpljenosti, depersonalizacije i osobnog postignuća. Osoblje s nepsihijatrijskih odjela ima više osobno postignuće i višu razinu emocionalne iscrpljenosti od osoblja sa psihijatrijskog odjela.

Nisu utvrđene razlike između osoblja s obzirom na partnerski i roditeljski status u dimenzijama sagorijevanja te varijablama mentalnog zdravlja. Jednako tako, na cijelom uzorku nisu utvrđene statistički značajne povezanosti duljine radnog staža i dobi s dimenzijama sagorijevanja, procjenom otpornosti na stres, procjenom zadovoljstva životom i izraženosti općih psihopatoloških smetnji. Međutim, utvrđene su razlike u obrascima povezanosti varijabli u uzorku osoblja sa psihijatrijskog i nepsihijatrijskih odjela koje ukazuju na složene odnose među varijablama s obzirom na specifičnosti radnog okruženja u kojem osoblje radi. Time se otvara niz istraživačkih pitanja o varijablama koje predstavljaju čimbenike rizika za razvoj sagorijevanja i psihičkih smetnji na pojedinim odjelima u bolničkom okruženju.

\section{LITERATURA}

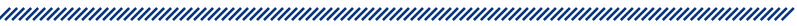

1. White RA. Perceived Stressors, Coping Strategies, and Burnout Pertaining to Psychiatric Nurses Working on Locked Psychiatric Units [magistarski rad]. Ypsilanti, Michigan: Eastern Michigan University; 2006. 93 str.

2. Bourbonnais R, Comeau M, Vézina M. Job strain and evolution of mental health among nurses. J Occup Health Psych. 1999; 4(2): 95-107.

3. Estryn-Behar M, Kaminski M, Peigne E, Bonnet N, Vaichere E, Gozlan C, et al. Stress at work and mental health status among female hospital workers. $\mathrm{Br} \mathrm{J}$ Ind Med. 1990; 47(1): 20-28.

4. Brown TG, Pragner T. Predictors of Burnout for Psychiatric Occupational Therapy Personnel. Can J Occup Ther. 1992; 59(5): 258-267.

5. Hudek-Knežević J, Krapić N, Rajter L. Odnos između emocionalne kontrole, percipiranog stresa na radnom mjestu i profesionalnog sagorijevanja kod medicinskih sestara. Psihologijske teme. 2005; 14(2): 41-54.

6. Ogresta J, Rusac S, Zorec L. Relation Between Burnout Syndrome and Job Satisfaction Among Mental Health Workers. Croat Med J. 2008; 49(3): 364-374.

7. Schaufeli WB, Leiter MP, Maslach C. Burnout: 35 years of research and practice. Career Dev Int. 2009; 14(3): 204-220.
8. Maslach C, Schaufeli BW, Leiter PM. Job burnout. Annu Rev Psychol. 2001; 52(1): 397-422.

9. Leiter MP. Burnout as a developmental process: Consideration of models. U: Schaufeli WB, Maslach C, Marek T, ur. Professional burnout: Recent development in theory and research. Washington DC: Taylor and Francis; 1993. 237-250.

10. Maslach C, Jackson ES, Leiter PM. Maslach Burnout Inventory Manual. 3. izd. Washington, DC: Consulting Psychologists Press; 1996.

11. Spooner-Lane R. The influence of work stress and work support on burnout in public hospital nurses [doktorska disertacija]. Queensland (AU): Queensland University of Technology; 2004. 431 str.

12. Tennant C. Work-related stress and depressive disorders. J Psychosom Res. 2001; 51(5): 697-704.

13. Knežević B. Stres na radu i radna sposobnost zdravstvenih djelatnika u bolnicama [doktorska disertacija]. Zagreb: Sveučilište u Zagrebu; 2010. 101 str.

14. Happell B, Martin T, Pinikahana J. Burnout and job satisfaction: A comparative study of psychiatric nurses from forensic and a mainstream mental health service. Int $J$ Ment Health Nurs. 2003; 12(1): 39-47.

15. Yousefy AR, Ghassemi R. Job burnout in psychiatric and medical nurses in Isfahan, Republic of Iran. East Mediterr Health J. 2006; 12(5): 662-669.

16. Dickinson T, Wright KM. Stress and burnout in forensic mental health nursing: a literature review. $\mathrm{Br} J$ Nurs. 2008; 17(2): 82-87.

17. Hamaideh SH. Burnout, Social Support, and Job Satisfaction among Jordanian Mental Health Nurses. Issues Ment Health Nurs. 2011; 32(4): 234-242.

18. Kilfedder CJ, Power KG, Wells TJ. Burnout in psychiatric nursing. J Adv Nurs. 2001; 34(3): 383-396.

19. Levert T, Lucas M, Ortlepp K. Burnout in Psychiatric Nurses: Contributions of the Work Environment and a Sense of Coherence. S Afr J Psychol. 2000; 30(2): 36-43.

20. Ndetei DM, Pizzo M, Maru H, Ongecha FA, Khasakhala LI, Mutiso V, et al. Burnout in staff working at the Mathari psychiatric hospital. Afr J Psychiatry. 2008; 11(3): 199-203.

21. Onyett $\mathrm{S}$, Pillinger T, Muijen M. Job satisfaction and burnout among members of community mental health teams. JMH. 1997; 6(1): 55-66.

22. Hanrahan NP, Aiken LH, McClaine L, Hanlon AL. Relationship between Psychiatric Nurse Work Environments and Nurse Burnout in Acute Care General Hospitals. Issues Ment Health Nurs. 2010; 31(3): 198-207.

23. Imai H, Nakao H, Nakagi Y, Niwata S, Sugioka Y, Itoh T, et al. Prevalence of burnout among public health nurses in charge of mental health services and emergency care systems in Japan. Environ Health Prev Med. 2006; 11(6): 286-291.

24. Patrick K, Lavery JF. Burnout in nursing. Aust J Adv Nurs. 2007; 24(3): 43-48.

25. Ćurčić $Đ$, Ćurčić M. Sindrom izgaranja kod zaposlenih u specijalnoj bolnici za psihijatrijske bolesti „Dr. Laza Lazarević". Engrami. 2009; 31(3-4): 19-28. 
26. Purvanova RK, Muros JP. Gender differences in burnout: A meta-analysis. J Vocat Behav. 2010; 77(2): 168-185.

27. Sahraian A, Fazelzadeh A, Mehdizadeh AR, Toobaee SH. Burnout in hospital nurses: a comparison of internal, surgery, psychiatry and burns wards. Int Nurs Rev. 2008; 55(1): 62-67.

28. Cañadas-De la Fuente GA, Vargas C, San Luis C, García I, Cañadas GR, De la Fuente El. Risk factors and prevalence of burnout syndrome in the nursing profession. Int J Nurs Stud. 2015; 52(1): 240-249.

29. Lin F, St John W, McVeigh C. Burnout among hospital nurses in China. J Nurs Manag. 2009; 17(3): 294-301.

30. Čular I. Sindrom sagorijevanja kod liječnika [diplomski rad]. Zagreb: Sveučilište u Zagrebu; 2010. 32 str.

31. Gobac A. Profesionalni stres kod dječjih kliničkih psihologa [diplomski rad]. Zagreb: Sveučilište u Zagrebu; 2016. 36 str.

32. Ivanda L. Sagorijevanje i izraženost emocionalnih smetnji medicinskih sestara na onkologiji i dermatologiji [diplomski rad]. Zagreb: Sveučilište u Zagrebu; 2016. 33 str.

33. Škrinjarić L. Stres kod pirotehničara [diplomski rad]. Zagreb: Sveučilište u Zagrebu; 2011. 38 str.
34. Evans C, Mellor-Clarck J, Margison F, Barkham M, Audin $\mathrm{K}$, Conell J, et al. CORE: Clinical Outcomes in Routine Evaluation. JMH. 2000; 9(3): 247-255.

35. Jokić-Begić N, Lauri Korajlija A, Jurin T, Evans C. Faktorska struktura, psihometrijske karakteristike i kritična vrijednost hrvatskoga prijevoda CORE-OM upitnika. Psihologijske teme. 2014; 23(2): 265-288.

36. Kararić D, Sindik J, Raguž V, Klokoč P, Milovčević V, Burum M. Odnos zadovoljstva životom i psihološke dobrobiti sa stresom i mentalnom čvrstoćom kod studenata sestrinstva. Hrvatski časopis za javno zdravstvo. 2012; 8(29): 35-48.

37. Hudek-Knežević J, Kalebić Maglica B, Krapić N. Personality, organizational stress, and attitude toward work as prospective predictors of professional burnout in hospital nurses. Croat Med J. 2011; 52(4): 538-549.

38. Hanrahan NP, Aiken LH, McClaine L, Hanlon AL. Relationship between psychiatric nurse work environments and nurse burnout in acute care general hospitals. Issues Ment Health Nurs. 2010; 31(3): 198-207.

39. Jaracz K, Górna K, Konieczna J. Burnout, stress and styles of coping among hospital nurses. Rocz Akad Med Bialymst. 2005; 50(Suppl 1): 216-219. 


\section{BURNOUT SYNDROME AND MENTAL HEALTH IN NURSES FROM PSYCHIATRIC AND NON-PSYCHIATRIC HOSPITAL WARDS}

The aim of this study was to investigate work-related burnout (defined by emotional exhaustion, depersonalization and perception of reduced personal achievement) and mental health (defined as resistance to stress, subjective quality of life and the expression of general psychopathological disturbances), and compare the level of burnout and mental health among nurses from various hospital wards. The participants were 123 nurses from non-psychiatric and 51 from psychiatric wards. Results for the entire sample indicate high levels of emotional exhaustion and moderate depersonalization and personal achievement among participants. Nurses are satisfied with their life, moderately resistant to stress and do not have pronounced psychopathological disturbances. The participants employed in non-psychiatric wards achieved high scores on the scale of emotional exhaustion and moderate results on the scale of personal achievement and depersonalization. The participants employed in the psychiatric wards achieved moderate results on the scale of emotional exhaustion, depersonalization and personal achievement. Nurses from non-psychiatric hospital wards have higher emotional exhaustion and higher personal achievement than those from psychiatric wards. There were no statistically significant differences in burnout and mental health considering partner and parental status in the overall sample. In psychiatric staff, longer work experience is associated with a higher level of depersonalization and a higher level of general psychopathological symptoms. On the other hand, in non-psychiatric staff, longer work experience is associated with a higher level of personal achievement and higher stress resistance. The results implicate that there are some differences between psychiatric and non-psychiatric nurses and their connection with the length of work experience that should be considered in planning burnout-related interventions.
Keywords: burnout, stress resistance, life satisfaction, mental health 